\begin{tabular}{|l|l|l||}
\hline \multicolumn{2}{|c|}{ PublisherInfo } \\
\hline \hline PublisherName & $:$ & BioMed Central \\
\hline \hline PublisherLocation & $:$ & London \\
\hline \hline PublisherImprintName & $:$ & BioMed Central \\
\hline \hline
\end{tabular}

\title{
Interferon' with lupus
}

\begin{tabular}{|l|l|l||}
\hline \multicolumn{2}{|c|}{ ArticleInfo } \\
\hline \hline ArticleID & $:$ & 294 \\
\hline \hline ArticleDOI & $:$ & $10.1186 /$ ar-2002-74050 \\
\hline \hline ArticleCitationID & $:$ & 74050 \\
\hline \hline ArticleSequenceNumber & $:$ & 47 \\
\hline \hline ArticleCategory & $:$ & Paper Report \\
\hline \hline ArticleFirstPage & $:$ & 1 \\
\hline \hline ArticleLastPage & $:$ & 3 \\
\hline \hline & & RegistrationDate $: 2002-1-6$ \\
& $:$ & Received \\
ArticleHistory & $:$ & Accepted \\
& & OnlineDate \\
\hline \hline ArticleCopyright & $:$ & Biomed Central Ltd2002-1-9 \\
\hline \hline ArticleGrants & $:$ & \\
\hline \hline
\end{tabular}




\begin{tabular}{|l|l|l|}
\hline ArticleContext & $:$ & 130754411 \\
\hline
\end{tabular}

Randy Q Cron, ${ }^{\text {Affl }}$

Affl Children's Hospital of Philadelphia, University of Pennsylvania, USA

\section{Keywords}

dendritic cell, interferon, systemic lupus,

\section{Context}

Type I interferons (IFNs) such as IFN-a are important mediators during antiviral responses. In normal individuals, plasmacytoid dendritic cells (DCs) are a major source of IFN-a in vivo. For about 2 decades, it has been known that elevated levels of type I IFNs are found in the serum of patients with systemic lupus erythematosus (SLE), a prototypic autoimmune disease. Moreover, treatment of various diseases with IFN-a often leads to antinuclear autoantibody production and frank autoimmunity, including SLE. The role that IFN-a has in SLE pathophysiology is just beginning to be explored.

\section{Significant findings}

Blanco and colleagues found that serum from SLE patients led to the differentiation of monocytes into DC in vitro. These differentiated monocytes exhibited several phenotypic features of mature DCs and they were capable of stimulating naive CD4 T cells to proliferate, a feature of professional antigen presenting cells (APCs) such as DCs. Furthermore, the DC-inducing capacity of SLE patients' serum strongly correlated with APC function. The differentiated DCs were shown to present antigen from apoptotic cells to autologous CD4 T cells. The capacity of SLE patient serum to induce DC differentiation was blocked with anti-IFN-a antibodies, and the levels of serum IFN-a correlated with the APC capacity of cells differentiated in SLE patient serum. Interestingly, CD123+ (IL-3 receptor-alpha chain) DC levels were found to be decreased in SLE patients' blood, but they were capable of normal IFN-a production upon viral stimulation. Depletion of CD123+ DCs virtually eliminated IFN-a production from normal individuals but only partially inhibited IFN-a from SLE patients' blood. Nonetheless, IFN-a might represent a therapuetic target in the treatment of SLE. 


\section{Comments}

It has recently been shown that SLE disease activity correlates with type I IFNs such as IFN-a (see Additional information). The paper reported here demonstrates that increased serum IFN-a in patients with SLE alters DC homeostasis. The authors' conjecture is that the increased DCs derived from monocytes may lead to increased antigen presentation and tip the balance of lymphocyte tolerance to autoimmunity. Whether this occurs in vivo is not currently known, and although the source of increased IFN-a production in patients with SLE is unclear, several labs have now demonstrated a connection between IFN-a and SLE. Therefore, IFN-a may be a key player in the pathophysiology of SLE.

\section{Methods}

Flow cytometry, mixed lymphocyte reaction, ELISA

\section{Additional information}

Ronnblom L, Alm GV: A pivotal role for the natural interferon alpha-producing cells (plasmacytoid dendritic cells) on the pathogenesis of lupus $J$ Exp Med 2001, 194(12): F59-63

\section{References}

1. Blanco P, Palucka AK, Gill M, Pascual V, Banchereau J: Induction of dendritic cell differentiation by IFN-a in systemic lupus erythematosus. Science. 2001, 294: 1540-1543.

This PDF file was created after publication. 